\title{
Development of Product Assessment Instrument Based on Contextual Learning
}

\author{
Sari Yustiana ${ }^{1 *}$, Rida Fironika Kusumadewi ${ }^{1}$ \\ ${ }^{1}$ Faculty of Teacher Training and Education, Sultan Agung University, Semarang, Indonesia \\ "Corresponding author. Email: sari.yustiana@ unissula.ac.id
}

\begin{abstract}
This research aimed to develop product assessment components and instruments based on contextual learning, and investigate the quality of the developed instruments. This development research applied the procedures developed which consists of 10 steps, namely: research and information collection, planning, developing preliminary of products, premilitary field testing, operational field testing, operational product revision, main field testing, main product revision, final product revision, dissemination and implementation. The validity of the instruments employed the content validity with Aiken' V formula, while the reliability of the instruments employed Cronbach Alpha. To find out the practicality and readability of the instrument used questionnaire responses of teacher and student. The results of the development in the form of product assessments are drawing mind maps, make a kolase, and draw poster. The expert judgment in the form of content validity is categorized 'Valid'. The reliability of the instruments is categorized 'Reliable' with Cronbach Alpha $>0.7$. The results of the teacher's response questionnaire showed a "Very Good" category that meant the product was already practical. Questionnaire student responses were analysed qualitatively and showed the product can be read well.
\end{abstract}

Keywords: assessment instrument, product, contextual learning

\section{INTRODUCTION}

Supporting the quality of human resources in a country is a good quality education. Good quality education would also support the progress of a nation. Thus, improving the quality of education is important to do. One of the ways to improve the quality of education is curriculum renewal. In Indonesia there have been several changes to the curriculum. The first curriculum was made at 1947 named Kurikulum 1947, until the curriculum that have been used nowadays since its first launch at 2013 named Kurikulum 2013.

Changes in curriculum has led to changes in material scope, competence level, and learning load, and also other things that related to learning implementation. These things are called as Standard of Content and Standard of Process. For example, there were some changes in lesson plans (RPP) in forms of learning approaches, learning models, and assessments. Learning approach used in the Kurikulum 2013 is thematic-integrative. This learning requires the integration of several subjects on one theme. The integration is carried out in two ways, namely the integration of attitudes, skills and knowledge in the learning process and integration of meaning of related concepts [1]. It has an impact on the assessment that should be done by the teacher. The assessment on Kurikulum 2013 is authentic assessment. The authentic assessment is different to conventional or standard assessment (paper and pencil test).
Authentic assessment has become a better replacement for the paper and pencil test [2].

The assessment should be carried out in real situations, so the learning designed by teacher should be real and meaningful too. The authentic assessment is suitable to be implemented because it is one of assessments that requires students to implement concepts or theories in real life [3]. One of ways to implement concepts in the real life is by conducting contextual learning. A new approach to evaluation is authentic assessment. This modality connects teaching to realistic and complex situations and contexts [4]. In this learning, students are invited to real learning activities. The point is that they really experience the learning, or learning is associated with the real conditions of students. Thus, learning would be more meaningful. If students could understand the meaning of learning activities, then students become more motivated to learn and understand the learning material better. Assignments given to students should also be meaningful, by connecting new knowledge with experiences they already have before. Contextual learning could encourage students to be more active, so it is superior to traditional learning in knowledge learning, applications and the transfer of learning to new situation [5]. This contextual learning is one that is recommended in the Kurikulum 2013, in addition to inquiry learning, discovery, project-based learning, and problem solving.

Authentic assessment evaluates students' attitudes, knowledge and skills. Attitude assessment consists of: selfassessment, peer-assessment, observation and journals. Knowledge assessment consists of written and verbal assessments. Skill assessment consists of: performanceassessment, project assessment, product assessment, and portfolio assessment. These three assessments are all 
related. Thus, the assessment conducted by the teacher should cover these three things.

Regarding learning material on Kurikulum 2013, especially in elementary schools since the enactment of this curriculum, there have been several changes in textbook, including the changes in guidance of learning outcomes assessment. This is confusing for the teacher. To assess student competency, the teacher observes on the assessment sheet in the textbook. In terms of authentic assessment concept, the assessment sheet in the teacher's book was incomplete, especially in skill assessment. The examples in the book were only on worksheets, and the evaluation rubric was incomplete. In addition, the rubric did not use measurable verbs, and there was no absentee.

Another obstacle in the assessment conducted by the teacher was the practicality of the instrument. This led to some teacher's task become meaningless, because the teacher did not do an analysis of student achievement on the task. The task was not even assessed. Especially for the tasks other than cognitive tasks. For example, when giving a task to make a kite, the teacher not only assessed students' knowledge about bangun datar (plane geometry), but their kite products were also judged based on their neatness or suitability.

A good instrument of assessment is one that could measure student competence appropriately. The criteria for a good assessment instrument are valid, reliable, and practical. Valid means being able to measure what should be measured. Reliability is related to the level of consistency, while practical means the instrument is easy to use. This research was conducted in elementary schools in UPTD Genuk District, Semarang City. Based on interviews with grade 4 teachers there, they had developed a knowledge assessment, but it was difficult to make a skill assessment, especially the product assessment. There was already a skill assessment in the textbook, which was a performance evaluation, but there was no product evaluation yet. Though there were several tasks to make products, such as making Kolase and drawing.

Product assessment is the assessment on process of product quality making created by the students. Product assessment has steps in its implementation. There are three steps to conduct. First is preparation step, including student skill to plan, find out and develop ideas, select and design product. The second is production step, including assessment on student skill to select and use material, tools and technique. Finally, the third is product assessment step, including assessment on result of students based on determined criteria [6].

The product assessment that had been made should meet the requirement of assessment instrument; valid, reliable and practical. The instrument validity is measured with content validity. The content validity: underlying concepts measured by the test [7]. The content suitability toward indicators was conducted through expert judgement. Reliability refers to consistency or stability of assessment result [8], so a data is considered reliable if it is obtained similar data when even analysed by different experts. The instrument practicality is also a standard requirement for an instrument. Practicality here refers to how easy the test is in preparation, implementation, processing, and interpretation and also administration [9].

The instrument developed was a skill assessment instrument, in the form of a product assessment sheet. The instrument was for grade 4 students in elementary school on the theme Indahnya Negeriku Subtheme Keindahan Alam Negeriku. The theme was selected based on the results of textbook analysis and interviews with class teachers. Based on the results of the analysis and interviews, the theme and the material presented were less contextual, because those were not in the student's environment. So, it was not real to them. In addition, the teacher also explained his confusion about the creation of a product assessment instrument. This was because there was no example in the teacher's handbook, although there were several tasks for making products that should be assessed.

Based on the need's analysis above, this research and development aimed to: (1) develop skill assessment in the form of instruments for product assessment based on contextual learning: (2) know the quality of the skills assessment in the form of instruments for product assessment based on contextual learning.

\section{METHOD}

This research was a research and development (R\&D). The subject of research was 4th grade students at UPTD Genuk, Semarang City. Preliminary field test was conducted within validation from 3 experts. Operational field test was conducted with 35 students at 4th grade in SD Gebangsari 01 . Main field test was conducted with 60 students at 4 th grade in SD Sembungharjo 01.

Procedure of Research and Development (R\&D) involved 10 steps, namely: 1) research and information collection; 2) planning; 3) developing preliminary of product; 4) preliminary field test, 5) operational field test; 6) operational product revision; 7) main field test; 8) main product revision; 9) final product revision; 10) dissemination and implementation [10].

Data collection techniques used interviews, product assessment sheets, teacher response questionnaire, and student response questionnaire. While technical data analysis was divided into preliminary data, and implementation data. Preliminary data is in the form of interviews and document analysis, as need-analysis data of teachers. Then the product development was conducted. The expert validation data used content validity, to determine the eligibility of the product based on the assessment and opinion of the experts. The trial data was used to determine product reliability. Then, the teacher and student response questionnaire were used to determine the practicality of the product being developed. Teacher responses were analysed quantitatively with the teacher giving grades, and qualitatively based on teacher suggestion. While the student response questionnaire was analysed qualitatively, that was only in the form of student comments on the meaningfulness of the assignments and the readability of the given assignment sheets.

The expert assessment on the product are as follows: 
Table 1 Expert assessment grid

\begin{tabular}{|c|c|c|c|c|}
\hline No & Aspect & Indicator & Items number & $\sum$ \\
\hline 1 & Material & Suitability of skill indicators with learning material & 1 & 1 \\
\hline \multirow[t]{2}{*}{2} & Construction & a. Use of psychomotor indicator. & 2 & 1 \\
\hline & & b. Clarity of work instructions and assessment criteria. & 3 & 1 \\
\hline \multirow[t]{2}{*}{3} & Language & a. Language effectiveness & 4,5 & 2 \\
\hline & & b. Use of spelling and grammar words/sentences & 6,7 & 2 \\
\hline \multirow[t]{2}{*}{4} & Contextual & a. The material is close to students. & 8 & 1 \\
\hline & & b. Real and meaningful task & 9,10 & 2 \\
\hline
\end{tabular}

The grids for the teacher response questionnaire is:

Table 2 Teacher response questionnaire grid

\begin{tabular}{|cllcc|}
\hline No & \multicolumn{1}{c}{ Aspect } & \multicolumn{1}{c}{ Indicator } & Items number & $\sum$ \\
\hline 1 & Construction & a. Clarity of charging instructions & 1 & 1 \\
& & b. Clarity of evaluation criteria & 2 & 1 \\
2 & Language & Understanding of indicators and rubrics on instruments & 4,5 & 2 \\
& & & 6,7 & 2 \\
3 & Contextual & a. The material is around students. & 8 & 1 \\
& & b. Real and meaningful task & 9,10 & 2 \\
4 & Practical & a. The shape and format of the instrument is easy to use & 8,9 & 2 \\
\hline & & & $\sum$ & 9 \\
\hline
\end{tabular}

The grids for students' responses questionnaire is:

Table 3 Teacher response questionnaire grid

\begin{tabular}{|c|c|c|c|c|}
\hline No & Aspect & Indicator & Items number & $\sum$ \\
\hline 1 & Construction & Readability of letters, images and tables & $1,2,3$ & 3 \\
\hline 2 & Language & Language is easy to understand & 4 & 1 \\
\hline \multirow[t]{2}{*}{3} & Contextual & a. The material is around students. & 5 & 1 \\
\hline & & b. Real and meaningful task & 6 & 1 \\
\hline \multirow[t]{2}{*}{4} & Practical & The shape and format of the instrument is easy to use & 8,9 & 2 \\
\hline & & $\sum$ & & 9 \\
\hline
\end{tabular}

The validity of the instrument uses the Aikens' V formula [11]:

$$
\begin{aligned}
& \mathrm{V}=\Sigma \mathrm{s} /[\mathrm{n}(\mathrm{c}-1)] \\
& \mathrm{s}=\mathrm{r}-\mathrm{lo} \\
& \text { lo }=\text { lowest validity rating number (in this case }=1 \text { ) } \\
& \mathrm{c}=\text { highest validity rating (in this case }=5) \\
& \mathrm{r}=\text { number given by an assessor }
\end{aligned}
$$

An item is considered as valid if the minimum co-efficient equals to $50 \%$ of $\mathrm{n}$ experts panel. The assessment here involved 3 experts, which meant that $50 \%$ of $3(n)$ is 1.5 . Then the 1.5 is divided to 3 (n) results the score of V coefficient as 0.5 . Thus, the product assessment instrument tis valid if the co-efficient is $\geq 0.5$. The teacher-response questionnaire was analysed quantitatively and qualitatively. Qualitatively, it was analysed based on suggestions and input from the teacher. Whereas quantitatively by changing the score into a scale of scores. So, the conversion scores is as follows:
Table 4 Conversion scores

\begin{tabular}{|ccc|}
\hline No & Aspect & Indicator \\
\hline 1 & $81-100$ & Excellent \\
2 & $61-80$ & Very Good \\
3 & $41-60$ & Good \\
4 & $21-40$ & Fair \\
5 & $<20$ & Poor \\
\hline
\end{tabular}

Result of the assessment of this product was at least in the Good category. While the student questionnaire responses were analysed qualitatively.

\section{RESULTS AND DISCUSSION}

Initial product from instruments of product assessment based on contextual learning on the theme Indahnya Negeriku subtheme Keindahan Alam Negeriku was a development based on research and information collection, namely: literature study, interviews, and document analysis. Research and information collection produce a needs analysis, that teachers need a skill assessment instrument, 
namely instruments od product assessment based on contextual learning.

The skill assessment in the form of product assessment refers to the material and learning activities. The material and learning activities are contextually developed. Product assessment is not conducted every day, but only on learning 2,4 , and 6 . In learning 2 , the assessment on the product was in the form of drawing a Mind Map. On the assignment, students wrote down their knowledge in the form of interesting drawings, supplemented with additional drawings, and made with colourful concepts. Then, in learning 4 the product assessment was in the form of making collage (kolase). First, students made some nature images based on their experiences. The part of nature embedded used materials that are around students, namely banana leaves. Banana leaves were used in different colours, such as the green colour of young leaves, yellowish, to dark brown from dry leaves. The final product assessment was on learning 6. Students were given the task of making posters about attractions around them. Posters were made with colourful pictures and writing.

The assessment of student product result refers to Permendikbud No. 104 at 2014 about product evaluation criteria, which includes preparation, product manufacturing process, and final product evaluation. Aspects of preparation include planning, tools, and materials. The aspects of the product manufacturing process include the preparation of tools and materials, processing techniques, and K3 (safety, security, and hygiene). While aspects of the final product evaluation include physical form, innovation, and timeliness.

Assessment by experts on instruments of product assessment is as follows:

Table 5 Expert on product assessment instrument

\begin{tabular}{|clcc|}
\hline No & Product Assessment & Score & Category \\
\hline 1 & Making a mind map & 0.842 & Valid \\
2 & Making a Collage (Kolase) & 0.842 & Valid \\
3 & Making a Poster & 0.816 & Valid \\
\hline
\end{tabular}

All instrument of product assessment had co-efficient $\geq 0.5$, so it was in valid category that was then tested on students. From the test, it was then analysed to determine the reliability of the instrument. The reliability result for each instrument are:

Table 6 Product-assessment instrument: making a mind map

\begin{tabular}{|clcc|}
\hline No & Product-Assessment & Score & Category \\
\hline 1. & Making a mind map & 0.834 & Reliable \\
2. & $\begin{array}{l}\text { Making a Collage } \\
\text { (Kolase) }\end{array}$ & 0.914 & Reliable \\
3. & Making a Poster & 0.834 & Reliable \\
\hline
\end{tabular}

All instruments of product assessment had co-efficient $>$ 0.7 , so they were all Reliable. After obtaining the validity and reliability of the instrument, it was then revised. The next step is the Operational field test to obtain teacher and student responses. Respondents from students were 35 students at 4th grade students in SD Gebangsari 01. The input was given in the form of sample products for each assignment. Result of the teacher's response questionnaire were analysed qualitatively and quantitatively. Qualitatively, input from the teacher was in the form of examples of products that need to be shown to students first. Then operational product revision was conducted to revise the product based on teacher and student input. The next step was main field testing. At this stage, the questionnaire responses of students were given to 60 students of 4 th grade in SD Sembungharjo 01. The students provided suggestions to clarify the picture. Input from the teacher was an assessment rubric that needs to be specified, so that assessment would become easier. While the results of the assessment based on the teacher's response questionnaire in the operational field test and main field testing are:

Table 7 Results of teacher response questionnaire on product assessment: making a mind map

\begin{tabular}{|clcccc|}
\hline No & Product Assessment & Operational field testing & Category & Main field testing & Category \\
\hline 1 & Making a mind map & 83.00 & Excellent & 87.00 & Excellent \\
2 & Making a Collage & 80.00 & Very Good & 86.00 & Excellent \\
& $\begin{array}{l}\text { (Kolase) } \\
3\end{array}$ & 81.00 & Excellent & 87.00 & Excellent \\
\hline
\end{tabular}

Result of operational field test indicated that the product assessment was in Good category, and there was an increase on the result of main field test into very good category. Furthermore, the product was considered proper or suitable. The next stage was main product revision, which was revising the product according to input from teachers and students. Then the final product was composed. Furthermore, a dissemination was conducted for teachers in the UPTD Genuk, Semarang City. Hopefully the result of product assessment development could be used as an alternative in learning process and could improve the quality of learning st schools.

Based on the results of the study, the skill assessment instrument in the form of product assessment is new for teachers. The skill assessment in the form of productassessment is actually already known by the teachers, but they teacher had difficulty developing it. The developed product assessment was based on learning activities undertaken by students. In addition, the assignment was also in accordance with the real situation of students, which is from their close environment, so it would be more meaningful for them. These are the characteristics of contextual learning. 


\section{REFERENCES}

[1] Tim Penyususn, Kurikulum 2013 kompetensi dasar untuk sekolah dasar (SD)/madrasah ibtidaiyah (MI), Kemendikbud, 2013.

[2] Azim \& Mohammad Khan "Authentic Assessment: an instructional tool to enhance student learning" in Scholary Journal, Vol 6, 2014, pp. 314-320.

[3] Djemari Mardapi, Pengukuran, Penilaian dan Evaluasi Pendidikan. Nuha Medika, Nuha Medika, Yogyakarta, 2012.

[4] R. Olfos \& H. Zulanty, Reliability and Validity of Authentic Asesement in A Web Based Course, in Educational Technology and Society, vol 10, 2007. pp.156-173.

[5] P.M Miller, Contextual Learning May Be a Better Teaching Model: A Case For Higher Order Learning and Transfer. In Proceedings of the Academy of Educational Leadership, Vol. 11 (2). 2006. Pp. 19-23. 